\title{
SPOTLIGHT ON MIGRATION
}

\section{COVID-19 and Venezuelan Refugees}

Veronica Escobar Olivo

Spotlight on Migration No. 2020/1

June 2020

The Spotlight on Migration Series is produced jointly by the

Ryerson Centre for Immigration and Settlement (RCIS) and the CERC in Migration and Integration

www.ryerson.ca/centre-for-immigration-and-settlement www.ryerson.ca/cerc-migration 


\title{
Spotlight on Migration
}

No. $2020 / 1$

\section{COVID-19 and Venezuelan Refugees}

\author{
Veronica Escobar Olivo \\ Ryerson University
}

Series Editors: Usha George and Anna Triandafyllidou

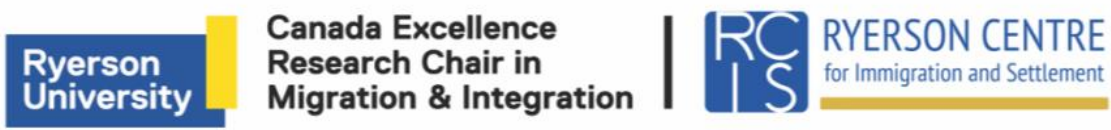

The Spotlight on Migration Series is produced jointly by the Ryerson Centre for Immigration and Settlement (RCIS) and the CERC in Migration and Integration at Ryerson University.

Spotlight on Migration pieces include a combination of research-informed overviews and blog posts focused on issues and questions related to migration. The purpose is to address popular misconceptions and generate discussion. The views expressed by the author(s) do not necessarily reflect those of the RCIS or the CERC in Migration and Integration.

For further information, visit www.ryerson.ca/centre-for-immigration-and-settlement and www.ryerson.ca/cerc-migration.

ISSN: 1929-9915

(c) (i) $@ \Theta$ Creative Commons Attribution-Noncommercial-No Derivative Works 2.5 EY No No Canada License 
As populations around the world adjust to a new reality shaped by the COVID-19 pandemic, across Latin America an estimated 113 million people living in low-income neighbourhoods are struggling to make ends meet with the ongoing lockdown and social isolation procedures (Phillips et al., 2020). In addition to the looming threat of infection, more impoverished populations must contend with the day-to-day struggle of trying to stay afloat financially and the actual feasibility of practising social distancing. Among the most vulnerable populations are refugees and migrants, who are exposed to even more significant hardships as governments attempt to navigate the pandemic (UNHCR, 2020). The already precarious financial situations and housing of most refugees have worsened as host countries make efforts to provide supports and programs for their populations - initiatives which do not necessarily take into account the situations of most refugees. For Venezuelan refugees in particular, the threat to their safety, security, and futures has been further compounded in the course of the pandemic.

Since the Venezuelan refugee crisis began, over 5 million Venezuelans (R4V, 2020) have sought protection in neighbouring countries in an attempt to flee violence, threats, insecurity, and a lack of food, medicine, and other essential services. The United Nations High Commissioner for Refugees (UNHCR) has called the crisis the most significant exodus in Latin America's recent history. The complete collapse of Venezuela has a long, complicated history. The downturn of the economy began in 1998, under the election of Hugo Chavez, a military officer who had attempted a coup six years earlier in 1992 (Fisher \& Taub, 2017). Under the guise of revolutionary ideals, he quickly plummeted the Venezuelan economy and destroyed any semblance of democracy. During his 2002 coup, Chavez found that siding with armed groups dubbed colectivos could help him retain power; these colectivos would prove increasingly violent and opportunistic, challenging police control, and legitimizing organized crime (Fisher \& Taub, 2017). Murder rates spiked, and, in 2013 after the death of Chavez, Nicolas Maduro inherited a country practically in shambles. Unable to garner the same support from the elite, Maduro struggled to maintain the economy and began printing more money, a tactic which drove up inflation and made importing increasingly expensive. Basic goods became unaffordable, public services disappeared, and armed gangs ran rampant (Kurmanaev, 2019). The Venezuelan crisis has been characterized by its extremes. In 2016, it was estimated that inflation had risen as high as 720 percent, and by the end of 2019 Venezuela's GDP will have decreased by 62 percent (Fisher \& Taub, 2017; Kurmanaaev, 2019).

The economic devastation has left Venezuelans vulnerable and has had rippling effects on neighbouring countries such as Colombia and Ecuador which are increasingly unable to deal with the mass influx of refugees. Ongoing oil sanctions, initiated by the United States' President Donald Trump in 2019, bar American companies from engaging in business transactions with Venezuelan oil companies (Wong \& Casey, 2019). These oil sanctions have furthered the desolation of the Venezuelan economy and, ultimately, its people. For those who had been able to escape the dangers of Venezuela and find refuge in neighbouring countries, COVID-19 has come as another violent uprooting. Venezuelans who have moved to border countries have mostly sought work in the informal labour market, which is excluded from most COVID-19 crisis-related financial assistance plans (ILO, 2020). According to the International Labour Organization (ILO), approximately 1.6 billion workers in informal economies stand in immediate danger of having their livelihoods destroyed (ILO, 2020). Confronted with the disappearance of the informal economy as neighbouring countries impose strict social distancing measures, Venezuelans are once again faced with the inability to financially provide, and the loss of income has seen thousands of Venezuelan migrants forced to return to Venezuela (Rueda, 2020).

As of now, there is no specific plan to help Venezuelan migrants. Refugees that are financially struggling in bordering countries are primarily excluded from national relief plans. 
A number of refugees have sought to return to Venezuela, hoping that coping with the pandemic will be more comfortable there. Upon arrival in Venezuela, however, returning refugees are being locked up in border towns, to be forced into unsanitary quarantines by officials. Despite a recent broadcast in which Maduro reassured returning Venezuelans that "the homeland welcomes you with open arms," the realities of those returning are quite stark (Grattan, 2020). The economic struggles which originally prompted most refugees to flee remain, but, with little hope in remaining financially afloat in bordering countries, most Venezuelans are unable to turn anywhere else. Countries such as Colombia and Ecuador, which are struggling to meet the needs of their own citizens, have opted to neglect the plight of refugees during the pandemic. While the violence and insecurity that Venezuelan refugees experience is not new, the current reality of Venezuelan refugees returning home in the absence of other options stands to remind us that, much like with other crises when global attention has shifted elsewhere, the struggles of these refugees continue. 


\section{References}

Barchfield, J. (2020, May 12). Coronavirus pandemic wreaks havoc on displaced Venezuelans. UNHCR. Retrieved from https://www.unhcr.org/news/stories/2020/5/5eb9d9374/coronavirus-pandemicwreaks-havoc-displaced-venezuelans.html

Fisher, M. \& Taub, A. (2017, May 14). How Venezuela stumbled to the brink of collapse. The New York Times. Retrieved from https://www.nytimes.com/2017/05/14/world/americas/venezuela-collapse-analysisinterpreter.html

Grattan, S. (2020, April 16). Returning Venezuelans in squalid quarantine face uncertain future. The Guardian. Retrieved from https://www.theguardian.com/globaldevelopment/2020/apr/16/venezuelans-returning-squalid-quarantine-migrants.

International Labour Organization (2020). COVID-19 crisis and the informal economy: Immediate responses and policy challenges. ILO Brief. Retrieved from https://www.ilo.org/wcmsp5/groups/public/---ed_protect/---protrav/--travail/documents/briefingnote/wcms_743623.pdf

Kurmanaev, A. (2019, May 17). Venezuela's collapse is the worst outside of war in decades, economists say. The New York Times. Retrieved from https://www.nytimes.com/2019/05/17/world/americas/venezuela-economy.html.

Mixed Migration Centre. (2020, June). Venezuelan refugees and migrants: awareness and information on COVID-19. Retrieved from https://data2.unhcr.org/en/documents/download/77275

Phillips, T., Goñi, U., Becerra Jimenez, C., Parra, L., Parkin Daniels, J. \& Agren, D. (2020, April 21). Lockdown leaves poor Latin Americans with impossible choice: Stay home or feed families. The Guardian. Retrieved from https://www.theguardian.com/world/2020/apr/21/latin-america-coronaviruslockdowns-low-income

Rueda, M. (2020, April 6). 'Nothing left:' Venezuelans head home amid coronavirus pandemic. Al Jazeera. Retrieved from https://www.aljazeera.com/news/2020/04/leftvenezuelans-head-home-coronavirus-pandemic-200406113000807.html

R4V. (2020, June 5). Response for Venezuelans. Regional Inter-Agency Coordination Platform for Refugees and Migrants from Venezuela. Retrieved from https://data2.unhcr.org/en/situations/platform

UNHCR. (2020). Venezuela Situation. Retrieved from https://www.unhcr.org/venezuelaemergency.html

Wong, E. \& Casey, N. (2020, January 28). U.S. targets Venezuela with tough oil sanctions during crisis of power. The New York Times. Retrieved from https://www.nytimes.com/2019/01/28/us/politics/venezuela-sanctions-trump-oil.html 